\title{
Pengembangan Bahan Ajar Konsep Suhu dan Kalor Berbasis Android
}

\author{
ST. Misbach, Sahrul Saehana, dan Darsikin \\ misbathaib28@gmail.com \\ Program Studi Pendidikan Fisika FKIP Universitas Tadulako \\ Jl. Soekarno Hatta Km. 9 Kampus Bumi Tadulako Tondo Palu - Sulawesi Tengah
}

\begin{abstract}
Abstrak - Tujuan dari penelitian ini adalah untuk mengetahui kelayakan aplikasi android. Penelitian ini merupakan penelitian pengembangan yang mengacu pada model ADDIE yang meliputi 5 tahap, yaitu Analisis, Perancangan, Pengembangan, Implementasi dan Evaluasi. Subjek penelitian adalah siswa kelas XI yang berjumlah 17 orang. Hasil uji coba dan analisis angket menunjukkan bahwa rata-rata skor penilaian ahli materi sebesar 3,22 dan dikategorikan "Baik", rata-rata skor ahli media sebesar 3,28 dikategorikan "Sangat Baik", analisis kelayakan oleh guru dengan skor rata-rata sebesar 3,51 dikategorikan "Sangat Baik" dan hasil analisis penilaian respon siswa diperoleh skor rata-rata sebesar 3,44 dan dikategorikan "Sangat Setuju". Hasil penelitian menunjukkan bahwa program bahan ajar berbasis android yang dikembangkan layak sebagai media pembelajaran bagi siswa.
\end{abstract}

Kata Kunci: bahan ajar, android, suhu dan kalor

\section{PENDAHULUAN}

Fisika merupakan cabang ilmu pengetahuan yang mempelajari tentang materi dari segala aktifitas fisik dari materi tersebut [1].

Menurut pandangan secara umum, masih banyak siswa yang menganggap mata pelajaran fisika sebagai salah satu pelajaran yang sulit sehingga berdampak pada rendahnya motivasi serta hasil belajar siswa. Kesulitan yang sering terjadi dalam pembelajaran fisika antara lain banyak memuat hal-hal yang abstrak dan pemahamannya banyak melibatkan kemampuan gambaran mental. Selain itu, fisika menjelaskan gejala alam yang cenderung bersifat verbal sehingga kekurangan dalam bahasa dapat menimbulkan bias dalam memahami konsep fisika itu sendiri [2].

Perkembangan teknologi tersebut jika dimanfaatkan dengan baik akan berdampak positif terhadap bidang pendidikan. Smartphone yang sebelumnya hanya dimanfaatkan sebagai gaya hidup dan sarana komunikasi saja, akan lebih bermanfaat jika digunakan sebagai sarana untuk belajar peserta didik. Saat ini smartphone Android belum banyak dimanfaatkan sebagai sarana untuk belajar fisika. Hal ini ditandai dengan masih minimnya aplikasi pembelajaran fisika berbasis smartphone Android yang bisa diakses secara luas. Kenyataan tersebut memunculkan kebutuhan adanya pengembangan-pengembangan konten/aplikasi berbasis smartphone yang lebih banyak, beragam, dan mudah diakses [3].

Bahan ajar adalah seperangkat bahan yang memuat materi atau isi pembelajaran yang "didesain" untuk mencapai tujuan pembelajaran [4]. Bahan ajar juga merupakan komponen yang memiliki peran penting dalam proses pembelajaran. Ketersediaan bahan ajar dapat membantu mahasiswa dalam memperoleh informasi tentang materi pembelajaran. Beberapa asumsi tentang arti penting kedudukan bahan ajar yaitu: 1) membantu belajar secara perorangan; 2) memberikan keleluasaan penyiapan pembelajaran jangka pendek dan jangka panjang; 3) rancangan bahan ajar yang sistematis memberikan pengaruh yang besar bagi perkembangan sumber daya manusia secara perorangan; 4) memudahkan pengelolaan proses belajar mengajar secara sistematis; dan 5) memudahkan dalam belajar [5].

\section{METODE PENELITIAN}

Penelitian ini termasuk jenis penelitian dan pengembangan atau dikenal Research and Developement (R\&D) yaitu model penelitian yang digunakan untuk menghasilkan produk tertentu, dan menguji keefektifan produk tersebut [6]. Secara lebih khusus pengembangan ini menggunakan model ADDIE.

Penelitian pengembangan bahan ajar konsep suhu dan kalor berbasis android, diadaptasi dari 
langkah-langkah model penelitian pengembangan oleh Sugiyono. Langkah-langkah penelitian secara umum seperti yang ditunjukkan pada Gambar 1.

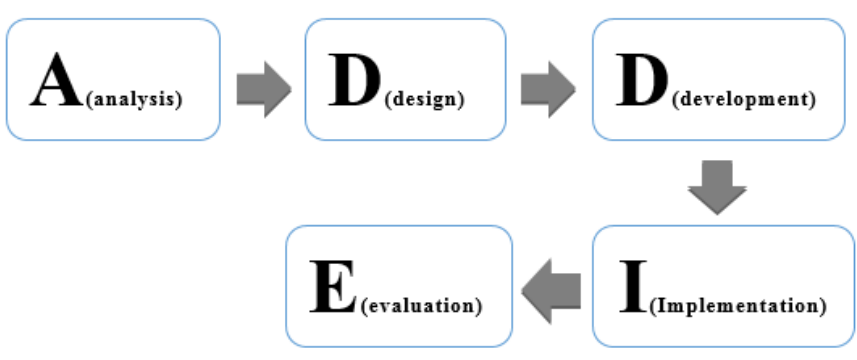

Gbr 1. Langkah-langkah Metode ADDIE

Langkah-langkah dalam penelitian dilaksanakan hingga tahap evaluasi. Dari gambar 1 maka langkah-langkah yang dilaksanakan meliputi:

1. Analysis

Analisis dalam penelitian ini meliputi analisis tujuan, analisis kurikulum dan materi, analisis tingkat kemampuan dan karakteristik sasaran pengguna.

2. Design

Meliputi perancangan butir-butir materi, penyusunan alur penyampaian materi dalam bentuk flowchat, pembuatan storyboard media, dan pengumpulan bahan-bahan yang dibutuhkan dalam pengembangan bahan ajar. Proses ini adalah proses dimana gambaran awal dari bahan ajar yang dikembangkan.

3. Development

Pada tahap ini bahan ajar yang telah selesai dibuat kemudian melalui uji validasi oleh ahli materi dan ahli desain. Uji validasi bertujuan untuk mengetahui validitas dari bahan ajar yang dihasilkan. Kemudian bahan ajar dievaluasi juga untuk melihat sejauh mana bahan ajar bisa dan layak digunakan. Melalui evaluasi kelebihan dan kekurangan bisa diketahui dan sangat memungkinkan untuk dilakukan perbaikan sehingga media pembelajaran bahan ajar ini menjadi lebih baik.

4. Implementation

Bahan ajar yang telah validasi diujicobakan kepada siswa. Setelah siswa mengikuti uji coba bahan ajar, selanjutnya siswa diminta untuk mengisi lembar kuisioner berupa tanggapan terhadap bahan ajar.

5. Evaluation

Setelah diuji coba produk kemudian dilakukan penilaian terhadap media yang dikembangkan, dilakukan empat tahap sebelumnya.
Penelitian ini dilaksanakan di SMA Negeri 1 Palu. Waktu pelaksanaan penelitian pengembangan ini selama 8 bulan. Subjek penelitian ini adalah siswa kelas IX SMA Negeri 1 Palu. Karena penelitian ini adalah penelitian dan pengembangan dengan uji terbatas, maka hanya 17 orang penelitian untuk menilai bahan ajar.

Intstrumen yang digunakan pada penelitian ini adalah angket yang diberikan kepada ahli materi, ahli media, guru mata pelajaran Fisika dan siswa sebagai responden.

Teknik analisis yang digunakan untuk menganalisis data hasil validasi adalah perhitungan nilai rata-rata. Penentuan teknik analisis nilai rata-rata ini berdasarkan pendapat dari Arikunto yang menyatakan bahwa untuk mengetahui peringkat nilai akhir pada setiap butir angket penelitian, jumlah nilai yang diperoleh dibagi dengan banyaknya responden yang menjawab angket penilaian tersebut [7]. Persamaan untuk menghitung nilai rata-rata adalah:

$$
\bar{X}=\frac{\sum x}{n}
$$

Keterangan :

$\overline{\boldsymbol{X}} \quad$ : nilai rata-rata dalam tiap butir pertanyaan

$\sum x$ : jumlah nilai dari seluruh penilaian dalam tiap butir pertanyaan

$\boldsymbol{n}$ : jumlah butir pernyataan

Cara Mengubah skor rata-rata yang diperoleh ke dalam bentuk kualitatif berdasarkan Tabel 1 [8].

TABEL 1 KATEGORI SKALA LIKERT

\begin{tabular}{cc}
\hline Skor & Interprestasi \\
\hline $3,25<\bar{X} \leqslant 4,00$ & Sangat baik (SB) \\
$2,50<\bar{X} \leqslant 3,25$ & Baik (B) \\
$1,75<\bar{X} \leqslant 2,50$ & Kurang (K) \\
$1,00 \leqslant \bar{X} \leqslant 1,75$ & Sangat Kurang (SK)
\end{tabular}

Analisis data respon siswa serupa dengan analisis kualitas penilaian produk. Rata-rata skor dari angket respon selanjutnya diubah ke dalam bentuk kualitatif berdasarkan Tabel 2 .

TABEL 2 KRITERIA KATEGORI RESPON MAHASISWA

\begin{tabular}{cc} 
TABEL 2 KRITERIA KATEGORI RESPON MAHASISWA \\
\hline Skor & Interprestasi \\
\hline $3,25<\bar{X} \leqslant 4,00$ & Sangat Setuju (SS) \\
$2,50<\bar{X} \leqslant 3,25$ & Setuju (S) \\
$1,75<\bar{X} \leqslant 2,50$ & Kurang Setuju (KS) \\
$1,00 \leqslant \bar{X} \leqslant 1,75$ & Tidak Setuju (TS)
\end{tabular}

Skor penilaian atau tingkat kelayakan baik setiap aspek maupun keseluruhan terhadap aplikasi bahan ajar menggunakan Tabel 1 dan Tabel 2, sebagai acuan penilaian data yang 
dihasilkan dari validitas ahli materi, ahli media, guru mata pelajaran serta uji coba pada siswa agar mempermudah dalam pemberian suatu kriteria nilai bahan ajar fisika berbasis android yang dikembangkan sudah layak atau belum untuk digunakan.

\section{HASIL DAN PEMBAHASAN}

\section{A. Hasil Penelitian}

1. Validasi Ahli Materi

Ahli materi adalah validator yang dipilih untuk menilai kelayakan dari aspek kurikulum, penyajian materi dan kontekstual pada bahan ajar yang dikembangkan. Validasi dilakukan oleh seorang dosen pendidikan fisika. Dari hasil validasi materi didapatkan hasil penilaian seperti pada Tabel 3.

\begin{tabular}{|c|c|c|c|}
\hline No & Aspek & Skor & Klasifikasi \\
\hline 1 & Kelayakan Isi & 3,06 & Baik \\
\hline 2 & Kelayakan Penyajian & 3,50 & Sangat Baik \\
\hline 3 & Penilaian Konstekstual & 3,12 & Baik \\
\hline & Rata-rata & 3,22 & Baik \\
\hline
\end{tabular}

Adapun tingkat pencapaian yang diperoleh dari hasil penilaian angket uji coba ahli materi yang dihitung dengan menggunakan Persamaan 1 , diperoleh jumlah nilai total sebesar 3,22 nilai tersebut menunjukkan bahwa materi termasuk dalam kategori baik.

Adapun saran dan kritik oleh ahli adalah:

1) Tambahkan pertanyaan konsep

2) Tahap kegiatan harus sampai pada penemuan siswa yang dinyatakan dalam bentuk kesimpulan atau pertanyaan

3) Penilaian harus kontekstual dan tidak terbatas pada tes.

2. Validasi Ahli Media

Ahli media adalah validator yang dipilih untuk menilai kelayakan dari aspek kualitas tampilan, desai tampilan dan keterlaksanaan. Validasi dilakukan oleh seorang dosen pendidikan fisika. Hasil penilaian oleh ahli media dapat dilihat pada Tabel 4.

TABEL 4 HASIL VALIDASI KELAYAKAN OLEH AHLI MEDIA

\begin{tabular}{cccc}
\hline No & Aspek & Skor & Klasifikasi \\
\hline 1 & Kualitas tampilan & 2,85 & Baik \\
2 & Desain tampilan & 3,50 & Sangat Baik \\
3 & Keterlaksanaan & 3,50 & Sangat Baik \\
\hline & Rata-rata & 3,28 & Sangat Baik \\
\hline
\end{tabular}

Adapun tingkat pencapaian yang diperoleh dari hasil penilaian angket uji coba ahli materi yang dihitung dengan menggunakan Persamaan 1, diperoleh jumlah nilai total sebesar 3,28 nilai tersebut menunjukkan bahwa media termasuk dalam kategori sangat baik.

Adapun saran dan kritik oleh ahli adalah:

1) Ukuran font diperbesar

2) Tambahkan icon untuk keluar dari aplikasi

3) Menu toolbar dalam aplikasi lebih diperbesar.

\section{Produk Hasil Pengembangan}

Aplikasi ini menyajikan enam fitur yang disetiap fiturnya terdapat beberapa ikon dan di dalam ikon termuat materi yaitu (1) suhu (2) pemuaian (3) kalor. Aplikasi yang dikembangkan memuat enam menu utama, yaitu tujuan pembelajaran, materi pembelajaran, uji kompetensi, daftar pustaka, profil, dan petunjuk pengguna. Menu "Tujuan Pembelajaran" untuk menunjukkan kompetensi yang harus dikuasai oleh siswa setelah menggunakan bahan ajar. Pada menu "Materi Pembelajaran" terdapat materi yang disajikan beserta contoh soalnya. Setelah mempelajari materi yang disajikan pada menu "Materi Pembelajaran", pengguna dapat mengetes pemahaman terhadap materi yang disajikan pada menu "Uji Kompetensi" berisi petunjuk pengerjaan soal dan terdiri dari 20 soal pilihan ganda dan 5 soal esai. Kemudian terdapat skor penilaian akhir. Menu "Daftar Pustaka" berisi beberapa referensi. Menu "Profil" berisi gambar dan informasi singkat tentang pengembang. Menu "Petunjuk Pengguna" berisi untuk membantu pengguna mengetahui fungsi-fungsi tombol yang dala dalam aplikasi. Tampilan media pembelajaran yang dikembangkan dapat dilihat pada lampiran.

4. Hasil Angket Respon Siswa

Pada tahap ini dilakukan uji terbatas pada 17 siswa di SMA Negeri 1 Palu. Hasil uji coba yang dilakukan menunjukkan bahwa bahan ajar berbasis android yang dikembangkan layak untuk digunakan sebgai media pembelajaran fisika. Hal tersebut dapat dilihat pada Tabel 5.

TABEL 5. HASIL ANALISIS RATA-RATA PENILAIAN RESPON SISWA

\begin{tabular}{|c|c|c|}
\hline No & Pernyataan & $\begin{array}{l}\text { Skor Rata- } \\
\text { rata }\end{array}$ \\
\hline 1 & $\begin{array}{l}\text { Bahan ajar berbasis android } \\
\text { memberikan motivasi dan ketertarikan } \\
\text { pada saya untuk belajar }\end{array}$ & 3,59 \\
\hline 2 & $\begin{array}{l}\text { Saya bisa belajar secara aktif dan } \\
\text { mandiri dengan bahan ajar }\end{array}$ & 3,65 \\
\hline 3 & $\begin{array}{l}\text { Saya bisa belajar sesuai dengan } \\
\text { kecepatan dan intensitas belajar } \\
\text { mandiri saya }\end{array}$ & 3,35 \\
\hline 4 & $\begin{array}{l}\text { Saya lebih senang belajar dengan } \\
\text { bahan ajar berbasis android daripada }\end{array}$ & 3,06 \\
\hline
\end{tabular}




\begin{tabular}{clc}
\hline \multicolumn{4}{c}{ hanya mendengarkan penjelasan guru } \\
saja
\end{tabular}

Adapun tingkat pencapaian yang diperoleh dari hasil penilaian respon siswa yang dihitung dengan menggunakan Persamaan 1, diperoleh jumlah nilai total sebesar 3,44 nilai tersebut menunjukkan bahwa aplikasi termasuk dalam kategori sangat baik.

Adapun saran dan kritik secara umum dari hasil tanggapan pada uji terbatas untuk bahan ajar berbasis android adalah:

1) Walaupun adanya aplikasi bahan ajar berbasis android, tetapi harus dibantu dengan penjelasan guru sehingga keduanya saling mengisi.

2) Lebih mengembangkan aplikasi agar bisa digunakan disemua jenis smartphone.

5. Hasil Angket Respon Guru

Untuk mengetahui kelayakan penggunaan aplikasi oleh guru, maka guru diberi lembar penilaian yang berkaitan dengan aplikasi.

TABEL 6 HASIL ANALISIS KELAYAKAN OLEH GURU

\begin{tabular}{clcc}
\hline No & \multicolumn{1}{c}{ Aspek } & $\begin{array}{c}\text { Rata-rata } \\
\text { Jumlah Nilai }\end{array}$ & Kategori \\
\hline 1 & Kurikulum & 3,00 & Baik \\
\hline 2 & Penyajian materi & 3,75 & Sangat Baik \\
\hline 3 & Evaluasi & 3,50 & Sangat Baik \\
\hline 4 & Kebahasaan & 3,33 & Sangat Baik \\
\hline 5 & Kualitas tampilan & 3,66 & Sangat Baik \\
\hline 6 & Desain tampilan & 4,00 & Sangat Baik \\
\hline 7 & Keterlaksanaan & 3,33 & Sangat Baik \\
\hline & Rata-rata & 3,51 & Sangat Baik \\
\hline
\end{tabular}

Adapun tingkat pencapaian yang diperoleh dari hasil penilaian angket uji coba guru yang dihitung dengan menggunakan Persamaan 1, diperoleh jumlah nilai total sebesar 3,51 nilai tersebut menunjukkan bahwa aplikasi termasuk dalam kategori sangat baik.

Adapun saran dan kritik oleh guru adalah:

1) Materi yang disajikan sebaiknya lebih disesuaian lagi
2) Tampilan sudah lumayan bagus, tetapi lebih menggunakan warna yang lebih netral.

\section{B. Pembahasan}

Penelitian pengembangan bahan ajar berbasis android pada materi suhu dan kalor untuk siswa SMA kelas XI ini bertujuan untuk mengetahui kelayakan sebagai media pembelajaran fisika. Selain itu, juga dapat memberikan manfaat bagi siswa dalam memahami konsep fisika, sekaligus memperbaiki kualitas pembelajaran melalui media yang inovatif serta dapat digunakan sebagai alat evaluasi pencapaian pengetahuan siswa setelah mengikuti pembelajaran.

Hasil dari penelitian pengembangan ini berupa aplikasi android dengan ukuran 0,93 MB yang dikembangkan dengan menggunakan Adobe Flash CS6 merupakan sebuah software yang didesain khusus oleh adobe dan program aplikasi standar authoring tool profesional yang digunakan untuk membuat dan bitmap yang sangat menarik untuk keperluan pengembangan situs web yang interaktif dan dinamis.

Berdasarkan penilaian ahli materi yang dilakukan oleh dosen fisika Universitas Tadulako yaitu bapak Dr. I Komang Werdhiana, M.Si, aspek yang dinilai dari bahan ajar ini meliputi kelayakan isi, kelayakan penyajian, dan kesesuaian dengan pendekatan kontekstual. Rata-rata hasil penilaian dari uji kelayakan isi adalah 3,06 dengan kategori "Baik" , rata-rata dari uji kelayakan penyajian adalah 3,50 dengan kategori "Sangat Baik", dan rata-rata penilaian dari uji kesesuaian dengan pendekatan kontekstual adalah 3,12 dengan kategori "Baik". Skor rata-rata keseluruhan dari ahli materi yaitu 3,22 dan dikategorikan "Baik". Dari hasil tersebut ahli materi menyatakan bahwa bahan ajar ini layak di uji cobakan dilapangan dengan revisi. Dari penilaian ahli materi terdapat beberapa aspek yang masih kurang yaitu aspek kelayakan isi pada indikator kemuktahiran modul poin 13 menggunakan contoh kasus yang terdapat dalam kehidupan sehari-hari, karena pada validasi awal belum disertakan contoh kasus yang terdapat dalam kehidupan sehari-hari karena lebih menyorot ke aspek-aspek yang lain. Demikian pada aspek kelayakan penyajian dan penilaian kontekstual.

Hasil penilaian ahli media yang dilakukan oleh dosen fisika Universitas Tadulako yaitu bapak Muhammad Jarnawi, M.Pd, aspek yang dinilai dari aplikasi bahan ajar ini meliputi aspek kualitas tampilan, desain tampilan dan keterlaksanaan. Rata-rata hasil penilaian dari aspek kualitas tampilan adalah 2,85 dikategorikan "Baik", rata-rata hasil penilaian dari aspek desain tampilan adalah 3,50 "Sangat 
Baik", dan rata-rata hasil penilaian dari aspek keterlaksanaan adalah 3,50 "Sangat Baik". Skor rata-rata keseluruhan dari ahli media yaitu 3,28 dan dikategorikan "Sangat Baik". Dari hasil tersebut ahli media menyatakan bahwa aplikasi bahan ajar layak untuk di uji cobakan dilapangan dengan revisi sesuai saran.

Selanjutnya dilakukan uji kelayakan penggunaan aplikasi kepada guru fisika SMA Negeri 1 Palu, yaitu ibu Isnawati, S.Pd. Aspek yang dinilai dalam kelayakan penggunaan ini adalah aspek kurikulum, penyajian materi, evaluasi, kebahasaan kualitas tampilan, desain tampilan dan keterlaksanaan. Skor rata-rata hasil penilaian dari aspek kurikulum adalah 3,00 dikategorikan "Baik", skor rata-rata dari penyajian materi adalah 3,75 dikategorikan "Sangat Baik", skor rata-rata dari evaluasi adalah 3,50 dikategorikan "Sangat Baik", skor rata-rata dari kebahasaan adalah 3,33 dikategorikan "Sangat Baik", skor rata-rata dari kualitas tampilan adalah 3,66 dikategorikan "Sangat Baik", skor rata-rata dari desain tampilan adalah 4,00 dikategorikan "Sangat Baik", dan skor ratarata dari keterlaksanaan adalah 3,33 dikategorikan "Sangat Baik", skor rata-rata keseluruhan dari uji kelayakan oleh guru adalah 3,51 dan dikategorikan "Sangat Baik".

Setelah dilakukan penilaian oleh ahli materi, ahli media dan guru, kemudian tahap selanjutnya dilakukan uji coba kepada siswa hasil pengembangan bahan ajar berupa aplikasi android ini diujikan kepada 10 siswa yang berada di SMA Negeri 1 Palu. Tujuan dilaksanakan uji coba ini adalah untuk mendapatkan gambaran respon siswa terhadap bahan ajar berupa aplikasi android yang dikembangkan. Hasil analisis respon siswa terhadap bahan ajar berupa aplikasi android menggunakan model ADDIE yang dikembangkan karena tipe pernyataan bersifat positif, maka nilai (score) untuk tiap pilihan jawabannya adalah sebagai berikut 4 (Sangat setuju), 3 (Setuju), 2 (Kurang setuju), dan 1 (Tidak setuju).

Uji dilakukan terhadap 17 siswa melalui pengisian angket yang memiliki 10 item pernyataan bersifat positif dengan 4 opsi atau pilihan. Setelah melakukan analisis diperoleh skor rata-rata sebesar 3,44. Berdasarkan kriteria kategori respon siswa, skor tersebut termaksud dalam kategori "Sangat Setuju". Dari hasil angket yang menunjukkan kategori "Sangat Setuju" maka dapat dikatakan bahwa aplikasi android yang dikembangkan ini layak digunakan sebagai media pembalajaran fisika.

Aplikasi android ini memiliki kelebihan dan kekurang dalam proses penelitian pengembangannya sehingga perlu tahap uji coba di lapangan. Kelebihan dari aplikasi ini antara lain mudah dalam pengoperasinya, memiliki ukuran yang tidak besar, terdapat konten gambar yang dapat mendukung atau menguatkan konsep yang disajikan, penggunaan kalimat yang singkat, padat, jelas dan komunikatif, serta dapat digunakan dimana saja dan kapan saja karena bersifat offline atau tidak memerlukan koneksi internet.

Adapun kekurangan dari aplikasi ini yaitu belum digunakan atau diterapkan fungsi math dalam proses memasukkan formula atau rumus fisika. Rumus yang masih berbentuk file gambar diubah bentuknya menjadi gambar vektor untuk mengakali tampilannya agar tidak terkesan seperti file gambar. Dan juga bahan ajar dalam aplikasi ini belum dilengkapi dengan animasi atau gambar bergerak.

\section{KESIMPULAN DAN SARAN}

\section{A. Kesimpulan}

Berdasarkan analisis data dan pembahasan, maka penelitian ini dapat disimpulkan bahwa :

1) Penelitian pengembangan bahan ajar berbasis android ini dilakukan berdasarkan langkah-langkah pengembangan model ADDIE yaitu analisis, desain, pengembangan, implementasi dan evaluasi. Hasil validasi yang diberikan oleh ahli materi, ahli media, dan uji kelayakan oleh guru serta 17 siswa menyatakan bahwa produk valid dan layak digunakan.

2) Pada hasil analisis ahli materi didapatkan skor penilaian rata-rata sebesar 3,22 dan dikategorikan "Baik", analisis penilaian ahli media didapatkan skor rata-rata 3,28 dan dikategorikan "Sangat Baik", analisis uji kelayakan oleh guru didapatkan skor penilaian rata-rata sebesar 3,51 dan dikategorikan "Sangat Baik", dan hasil analisis penilaian respon siswa didapatkan skor rata-rata sebesar 3,44 dan dikategorikan "Sangat Setuju". Hal ini menunjukkan bahwa produk bahan ajar berbasis android yang dikembangkan ini dapat dijadikan sebagai salah satu media pembelajaran bagi siswa.

\section{B. Saran}

Berdasarkan penelitian yang dilakukan, adapun saran peneliti dalam mengembangkan bahan ajar berbasis android adalah:

1. Produk bahan ajar berbasis android pada materi suhu dan kalor untuk siswa SMA kelas $X I$ ini masih perlu dikembangkan dan 
disempurnakan lagi agar menghasilkan produk yang lebih berkualitas.

2. Lebih mengembangkan aplikasi agar bisa digunakan disemua jenis smartphone.

3. Mengembangkan aplikasi yang lebih inovatif lagi.

4. Ditinjau dari keterbatasan waktu peneliti dalam proses melaksanakan penelitian pengembangan ini, maka disarankan agar penelitian selanjutnya dapat dilaksanakan uji coba dalam skala lebih luas di sekolah lain.

\section{DAFTAR PUSTAKA}

[1] P. A. Tipler. Fisika untuk Sains dan Teknik jilid 1 (edisi ke-3). Jakarta: Erlangga. 1998.

[2] R. Prima. Pengembangan Modul Elektronik Fisika Sebagai Media Instruksional Pokok Bahasan
Hukum Newton pada Pembelajaran Fisika di SMA.Probolinggo:Universitas JEMBER. 2013.

[3] J. Prayiyadi. Pengembangan Aplikasi Mobile Learing Fisika Berbasis Smartphone Android pada Pokok Bahasan Keteraturan Gerak Planet Sebagai Sarana untuk Memfasilitas Kemampuan Analisis Peserta Didik Kelas XI SMA. Skripsi pada Program Studi Fisika Fakultas Sain dan Teknologi, Universitas Islam Negeri Sunan Kalijaga Yogyakarta. 2014. Tidak diterbitkan.

[4] Sungkono. Pengembangan dan Pemanfaatan Bahan Ajar Modul dalam Proses Pembelajaran. Makalah Yogyakarta: FIP UNY. 2003.

[5] A.H. Hernawan., Permasih dan L. Dewi. Pengembangan Bahan Ajar. Jakarta: UPI (KTI). 2008.

[6] Sugiyono. Metode Penelitian Kuantitatif, Kualitatif, dan R\&D, Bandung: Alfabeta. 2010.

[7] S. Arikunto. Prosedur Penelitian: Suatu Pendekatan Praktik. Jakarta: Rineka Cipta. 2006.

[8] Widoyoko. Teknik Penyususn Instrumen Penelitian. Yogyakarta: Pustaka Pelajar. 2012. 


\section{LAMPIRAN}

Gambar Produk Yang Dihasilkan

1. Loading

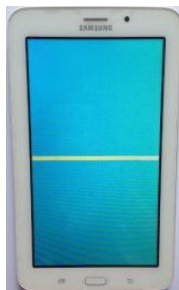

Gbr 1. Tampilan Loading

Loading merupakan tampilan sekilas sebelum home. Ketika aplikasi dibuka yang diatur waktu atau durasi tampilannya. Durasi tampilan loading ini diatur selama 5 detik.

\section{Home}

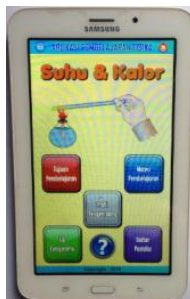

Gbr 2. Tampilan Home

Tampilan home muncul secara otomatis setelah splashscreen. Tampilan ini terdiri dari judul dengan teks APLIKASI PEMBELAJARAN FISIKA "Suhu \& Kalor", tombol menu yaitu menu petunjuk penggunaan, tujuan pembelajaran, materi pembelajaran, uji kompetensi, daftar pustaka, profil pengembang serta tombol untuk kembali kehalaman utama dan tombol untuk keluar.

3. Petunjuk Penggunaan

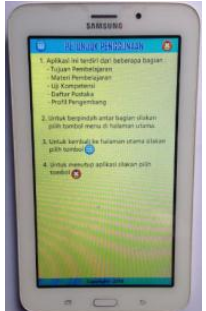

Gbr 3. Tampilan Petunjuk Penggunaan

Tombol petunjuk penggunaan berfungsi untuk membantu pengguna untuk mengetahui fungsifungsi tombol yang ada dalam aplikasi.

4. Tujuan Pembelajaran

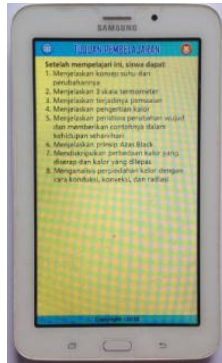

Gbr 4. Tampilan Tujuan Pembelajaran

Tujuan pembelajaran dibuat untuk menunjukkan kompetensi yang harus dikuasai oleh siswa setelah menggunakan bahan ajar. Tampilan tujuan pembelajaran pada aplikasi ini berbentuk list yang terdiri dari delapan tujuan.

5. Materi Pembelajaran

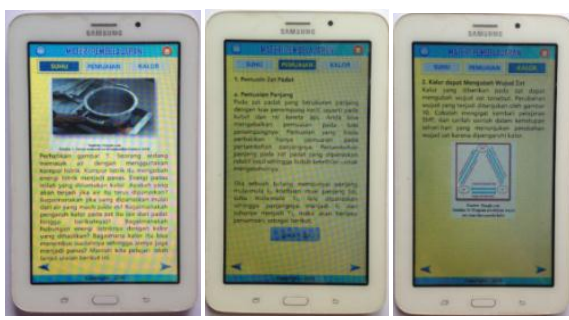

Gbr 5. Tampilan Materi Pembelajaran 
Tampilan materi pembelajaran berbentuk tab layout yang terdiri dari tiga tab, yaitu tab materi suhu, pemuaian dan kalor. Teks dibuat singkat, jelas serta komunikatif dan memiliki gambar diam.

\section{Uji Kompetensi}

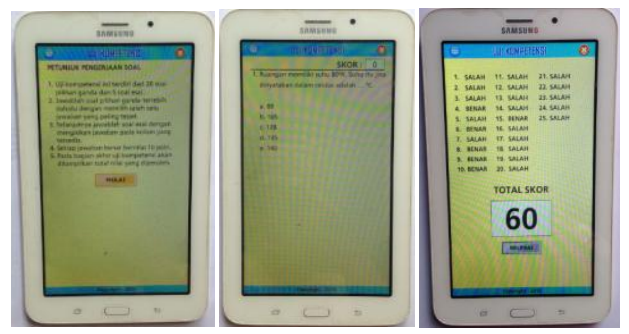

Gbr 6. Tampilan Uji Kompetensi

Di dalam tampilan uji kompetensi terdapat petunjuk pengerjaan soal. Uji kompetensi ini terdiri dari 20 soal pilihan ganda dan 5 soal esai. Di dalam menu uji kompetensi terdapat tombol MULAI, untuk memulai pengerjaan soal. Setiap soal jawaban benar bernilai 10 poin. Untuk melanjutkan ke nomor soal berikutnya terlebih dahulu memilih salah satu jawaban yang paling tepat.

7. Daftar Pustaka

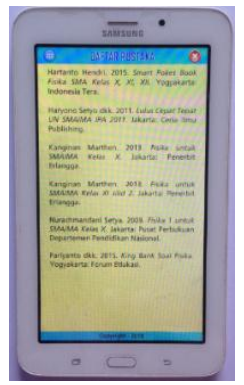

Gbr 7. Tampilan Tujuan Pembelajaran
Daftar pustaka terdapat beberapa reverensi untuk membuat bahan ajar.

8. Profil Pengembang

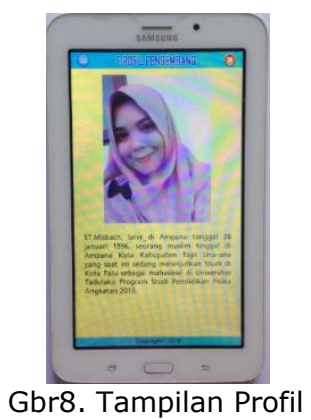

Tampilan menu profil berisi gambar dan informasi singkat tentang pembuat atau pengembang aplikasi.

9. Tombol Exit

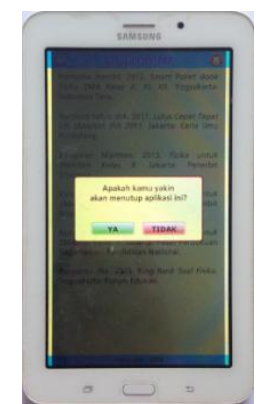

Gbr 9. Tampilan Exit

Tombol exit berfungsi untuk keluar dari aplikasi. Dan dilengkapi dengan dialog teks "Apakah kamu yakin akan menutup aplikasi ini?" kemudian terdapat opsi teks "YA" dan "TIDAK". 